\title{
Little Bo-Peep Has Lost Her Sheep, and Doesn't Know Where to Find Them: or, In Search Yet Again of Czechness and Czech Music
}

Geoffrey Chew / geoffchew1@gmail.com

Royal Holloway (University of London), UK

\begin{abstract}
In an article in 1986, Michael Beckerman debated the meaning of "Czechness" in music; since then, it has usually been construed as a myth that has more to do with the reception of the national repertoire than with objective qualities of the music. This article proposes that the idea of "Czechness" should be reconsidered, using not only ideas developed in historical musicology since the 1980s, but also more recent developments in music analysis, in order to redirect attention to "the music itself" and to reconstrue it in new and fruitful ways.
\end{abstract}

\section{Keywords}

cultural history, Czechness, Janáček, mythology, nationalism, polka, Smetana, transculturation 
This paper takes events of 2018 as its points of departure: the celebration of the centenary of the founding of Czechoslovakia in 1918, and the recent death of John Tyrrell, scholar of Czech music, who contributed so much to the understanding of Janáček, arguably the greatest of the composers of 20th-century Czechoslovakia. Originally it had only the Czech title, "Kam zmizela? Českost a hudba ve 20. století"; but the English translation I have suggested for that title also refers to a well-known English nursery rhyme, and refers additionally to a famous article by Michael Beckerman, which I think deserves to be re-assessed. In this way I hope to offer some reflections on the understanding of the national musical legacy of Czechoslovakia, not only by Czechs and Slovaks, but also by foreigners like myself who share the love and sympathy for Czech culture of both John Tyrrell and Michael Beckerman. And, with a nod to Tyrrell and his work, I shall mention Janáček in particular, but I shall start with some personal reminiscences.

As a student in the 1960s, I was recommended to choose a topic in Czech music as the subject for my PhD from the University of Manchester, and I chose the pastorella of the 18th century. At the time I knew the subject from Supraphon LPs, and from the repertory published in Musica antiqua bohemica. Nothing had been written about it in English, and nothing extended had then been written in Czech either. But I had also come across pastorellas from German-speaking Austria, and it seemed to me that a study across linguistic and modern national borders might prove original. It seemed to me that some sort of national identity was being claimed for both the Czech and the Austrian/German repertoires, and that they might be parts of a wider common repertoire.

Very fortunately, that turned out to be partly true. I was lucky to find that sources were available and fruitful, and I was able to defend my thesis successfully. But I had not fully realized how sensitive that question of nationality still was even in the Thaw of the 1960s, and for that subject in particular. In the 1930s, Zdeněk Nejedlý had discussed pastorellas in his big unfinished biography of Smetana, to illustrate the composer's attitude to the music of the 18th- and 19th-century schoolmasters and cantors. There Nejedlý had suggested that these cantors had played a vital role in preserving českost, the essence of the nation, in culture through the temno, the "darkness", as the author Alois Jirásek had termed it, ${ }^{1}$ of the period between the Battle of the White Mountain in 1620 and the Czech National Revival of the late 18th and 19th centuries. Himself the son of a cantor, Nejedlý suggested that the cantors had been guerrilla fighters, resisting the hegemonic power of the feudal authorities in the authentic Czechness of their music, and preserving the beauty of healthy Czech folk culture for the future of the nation. In his words,

our cantors, like our people in general, ... transformed this task of theirs into something quite different... They turned the church into a theatre, or, better, a concert hall, where music was played not in order to heighten the splendour of the church, but rather to allow the people to hear something beautiful, and to allow the local musicians to play something beautiful. ${ }^{2}$

1 JIRÁSEK, Alois. Temno: Historický obraz, Prague: J. Otto, 1915.

2 NEJEDLÝ, Zdeněk. Bedřich Smetana, Prague: Hudební matice Umělecké besedy, 1924-33, vol. 3 (Praha a venkov, 1929), p. 410: "Naši kantoři, jako náš lid vưbec, obrátili si brzo tuto svou úlohu v něco docela jiného. [...] 
This is the legacy, alleged Nejedlý, inherited by Smetana, the key figure in whom the českost of modern and future Czech music is assured. So the supposed českost of the music of the cantors became something not merely of historical interest, but political and polemical. The specific Czech features of their music were only vaguely defined by Nejedlý, but he somehow made their output a musical precursor to the polkas in Smetana's $x u v r e$, which Nejedlý came to fetishize as a genre on which musical českost depends. Later in that biography he writes:

For Smetana the polka was something more than a fashionable dance. For him it is ... a typically Czech dance ... a dance of Czech society and ... primarily a sign of českost. ... And not merely Czech, but domestic ... And therefore, where he wishes to express himself personally, intimately, from the heart, he writes and composes polkas. ${ }^{3}$

With this strong suggestion, českost, in polkas allegedly composed in the spirit of Smetana, became one of the touchstones of loyalty to the new political order after 1948, as is well-known. And though Nejedlý had insisted that Smetana's polkas were by definition personal and intimate, new polkas did not need to be so, to merit the label of českost. Václav Dobiáš, for example, produced what one might describe as a polka héroïque, a bombastic apotheosis of the genre, in his prizewinning cantata Buduj vlast, posiliśs mír! of 1948, with its subtitle Československá polka. ${ }^{4}$

However, it seems that new polkas could not automatically merit the label of českost, especially if they were satirical - even in the spirit of Hašek's Good Soldier Švejk. The pressure to conform to criteria imposed by Party criticism was evidently heavy in some cases. In 1952, Jan Novák had composed some polkas to be broadcast by Czechoslovak Radio, which incorporated a derisive "raspberry" motif. He was summoned to an interview at the Brno branch of the Union of Czechoslovak Composers, the Svaz československých skladatelů, on 16 June 1952. Helpful Party colleagues criticized him for being ignorant of modern life, "neznalý dnešního života", for failing to understand its realities, in which the workers, who provided him with his livelihood and with the opportunity for composing, expected an accessible piece with real feeling, a kitsch piece of real "beauty". ${ }^{5}$

So within the world of Stalinist Socialist Realism, českost, like beauty, could be defined only through Party criticism, which was regarded as a "co-creator" of music, even in the

Učinili z kostela divadlo či ještě lépe koncertní síň, kde se hudba provozovala ne tak aby zvyšovala lesk církve, jako spíse proto, aby si tu lid něco pěkného poslechl a mistni hudebníci aby si tu něco pěkného zahráli."

3 NEJEDLÝ, Zdeněk. Bedřich Smetana, vol. 4 (Ve společnosti, 1933), pp. 334-5: "Smetanovi byla [polka] něco víc než jen módni tanec. Jemu je to [...] typicky český tanec [...] tanec české společnosti, a tím př́mo znak českosti. [...] Nikoli však jen český je to Smetanovi tanec, $i$ vůbec domácí, jak domácí je mu právě český svět. A proto i kde se chce projevit osobně, intimně, srdě̌ně, píš a skládá polku."

4 DOBIÁŠ, Václav. Buduj vlast, posilíš mír! (československá polka): kantáta pro smišený sbor a orchestr na text Františka Halase, Prague: Národní hudební vydavatelství Orbis, 1951.

5 Typescript minutes of the meeting, which I accessed some years ago in the Musicological Institute, Masaryk University, Brno: "Pohovor s Janem Novákem. ... S[oudruh] Křivinka: ... Jan Novák je neznalý dnešního života. ... S[oudruh] Podešva: ... Pracující mu dávají možnost, aby tvořil, chtějí kus oprávdového citu, něco krásného.” 
seemingly uncomplicated world of polkas; it was indeed defined in these terms in the title of one of the manifestoes of Stalinist musical aesthetics in Czechoslovakia. ${ }^{6}$

But even without such political manipulation, Czech national character in music always has been problematic. And this question was memorably discussed more than 30 years ago in a famous article by Michael Beckerman. In that article he looked back on the Czech repertoire since the National Revival, and on the self-image of Czech composers from Smetana and Dvořák through to Janáček, Kaprál, Martinů, and Husa, though tactfully avoiding any mention of the part that was still being played by political pressure when he wrote. His final formulation is worth quoting in full:

We may [...] make a distinction between "the Czech style" and "Czechness" itself. While the former [(Czech style)] may be considered a series of descriptive or analytic generalizations based on the actual characteristics of a body of music, "Czechness" itself comes about when, in the minds of composers and audiences, the Czech nation, in its many manifestations, becomes a subtextual program for musical works, and as such, it is that which animates the musical style, allowing us to make connections between the narrow confines of a given piece and a larger, dynamic context. ${ }^{7}$

I think the full implications of Beckerman's article have been lost to some extent in the decades of scholarship on Czech music that have followed, particularly since the Velvet Revolution of 1989, and in my opinion they would be well worth recovering.

The relative novelty of that article in the 1980s was its tactful but firm insistence that national characteristics in music cannot be perceived without a kind of myth-making. And this myth-making is closely tied to the reception of the music. That excellent point has been thoroughly taken to heart - one can think of plenty of examples of more recent musical scholarship dismantling myths in Czech music. Random international examples from the last 20 years are the impressive monograph of 2001, on Smetana and Czech nation-building, by Christopher P. Storck, ${ }^{8}$ the wide-ranging article of 2009 by Mikuláš Bek, demythologizing Martinů, ${ }^{9}$ and the monograph on Smetana by Kelly St Pierre that appeared in 2017. ${ }^{10}$

Now I am not the first person to notice that the 1980s marked a turning-point in musicology, towards increasing fragmentation, into separate disciplines that do not com-

6 SYCHRA, Antonín. Stranická hudebni kritika spolutviorce nové hudby: Úvod do hudebni estetiky socialistického realismu. Za novou hudbu, vol. 3, Prague: Orbis, 1951.

7 BECKERMAN, Michael. In Search of Czechness in Music. 19th-Century Music, vol. 10, no. 1 (1986), pp. 61-73 (this quotation at p. 73).

8 STORCK, Christopher P. Kulturnation und Nationalkunst: Strategien und Mechanismen tschechischer Nationsbildung von 1860 bis 1914, Mittel- und Osteuropawissenschaften, Geschichte, Köln: Verlag Wissenschaft und Politik, 2001.

9 BEK, Mikuláš. Legendenbildung: Martinůs Rezeptionsgeschichte. Österreichische Musikzeitschrift, vol. 64, issue 11-12 (2009), pp. 14-21; Czech version in "Legenda o Bohuslavu Martinů: Př́íspěvek k dějinám recepce díla a života českého skladatele”, Kontexty, vol. 2 (2010), no. 1.

10 ST PIERRE, Kelly. Bedřich Smetana: Myth, Music, and Propaganda, Eastman Studies in Music, Rochester, NY: University of Rochester Press, 2017. 
municate with one another. Cultural studies, occupied with the critique of myth-making, has become very suspicious of any suggestion that the notes on the page represent TMI, "the music itself", and often avoid any type of music analysis or close reading. And analysis too, the discussion of what Beckerman in his 1986 article was still able to call the "actual characteristics" of a body of music, has become more specialized and sometimes inaccessible to those not professionally involved in it.

A side-effect of this fragmentation has been the partial discrediting of českost, too, as a respectable subject of enquiry, and its disappearance from the literature except in reception history. Even Janáček's speech-melodies, his nápěvky mluvy, may in retrospect have come under unjustified suspicion as a marker of the Czechness of Janáček's music, since a famous article by John Tyrrell, from as long ago as 1970, referred pointedly to the "speech-melody myth". ${ }^{11}$ And work such as that by Storck, Bek, and St Pierre, which I mentioned a moment ago, is unashamedly cultural history, in which The Music Itself has almost disappeared over the horizon, and is not discussed technically at all except as far as is necessary to explicate reception history and myth-making.

How, then, might we still go in search of českost and The Music Itself, Little Bo-Peep's missing, wandering sheep, assuming that they exist at all? How might we bring them home, safely back into the sheepfold, reconciling cultural history, and its "subtextual programs", as Beckerman called them, with music analysis? I would suggest that those of us concerned with understanding Czech music and its distinctiveness should take stock of some of the attempts that have been made in recent years to do this for other repertories, by taking some approaches of pre-1980 traditional musicology, together with some from the New Musicology that has mostly rejected them, and reformulating them in a new synthesis.

There is no space here to list all such programmes, and it may be best just to mention one. This is Shay Loya's Liszt's Transcultural Modernism and the Hungarian-Gypsy Tradition, published as recently as 2011, summarizing the author's work on the mutual interpenetration of nationalism and traditional elements in Liszt's music to construct, as he argues, a distinctive modernism. ${ }^{12}$ This takes place, he suggests, through "transculturation". The term, invented in 1940 by a Cuban scholar, Fernando Ortíz, and now widely accepted in postcolonial studies, describes the formation of new, syncretic cultures, such as those created through contact and interactions between dominant colonial cultures and indigenous ones. Thus Loya is able to bypass suggestions that national identity in Liszt's music depends on ancient, timeless elements of any sort, while giving full recognition to the interplay between the norms of received high culture and those musical elements that Liszt constructs, rightly or wrongly, as authentically national, and using the full resources of music analysis as these have been developed in recent decades.

No doubt this is not the only possible model that might be used for the purpose, but it, or another such approach, seems likely to open up new possibilities for studying the originality and novelty of much of the music of the Czech National Revival and later. It

11 TYRRELL, John. Janáček and the Speech-Melody Myth. The Musical Times, vol. 111 (1970), pp. 793-796.

12 LOYA, Shay. Liszt's Transcultural Modernism and the Hungarian-Gypsy Tradition. Eastman Studies in Music, Rochester, NY: University of Rochester Press, 2011. 
might be particularly rewarding for the music of Smetana, Liszt's close associate, perhaps allowing old debates about his uniqueness and originality to be revisited, about his dependence on Wagner, or the alleged over-dependence of his Vyšehrad on Fibich's tone-poem Záboj, Slavoj a Luděk of $1873 .{ }^{13}$

But in this centenary year of the founding of Czechoslovakia, in a Europe increasingly obsessed with questions of old-fashioned nationalism, I'd suggest particularly that an approach of this sort might prove useful for the music of Janáček. The originality and modernism of the second quartet, say, is not easy to establish. Janáček himself claimed it was written in a new style of "fire", superseding the "hot ash" of earlier pieces, and yet, in the words of Arnold Whittall, it

still acknowledges the long-standing distinctions between consonance and dissonance, and still relies, not only on archetypal generic qualities of song and dance, but also on ways of constructing melody that owe as much to folk traditions as to those of art music. ${ }^{14}$

Its distinctive modernism might emerge in a stronger light if viewed through Ortiz's "transculturation" - or some other lens through which Bo-Peep's sheep can come into view and be brought home safely.

So the questions of nationality that I found in Czechoslovakia in 18th-century pastorellas, all those years ago, seem still to be vital ones, but seem able to be approached and discussed today far more fruitfully and promisingly than seemed possible then. It seems a challenge worth taking on.

\section{Bibliography}

BECKERMAN, Michael. In Search of Czechness in Music. 19th-Century Music, vol. 10, no. 1 (1986), pp. 61-73

BEK, Mikuláš. Legendenbildung: Martinůs Rezeptionsgeschichte. Österreichische Musikzeitschrift, vol. 64, issue 11-12 (2009), pp. 14-21. Czech version: Legenda o Bohuslavu Martinů: Příspěvek k dějinám recepce díla a života českého skladatele. In: Kontexty, vol. 2 (2010), no. 1

DOBIÁŠ, Václav. Buduj vlast, posilišs mír! (československá polka): kantáta pro smišený sbor a orchestr na text Františka Halase, Praha: Národní hudební vydavatelství Orbis, 1951

JIRÁSEK, Alois. Temno: Historický obraz, Praha: J. Otto, 1915

LOYA, Shay. Liszt's Transcultural Modernism and the Hungarian-Gypsy Tradition, Eastman Studies in Music, Rochester, NY: University of Rochester Press, 2011

13 On the latter point, see especially the discussion in ST PIERRE, Bedrich Smetana. Chapter 2, based on the same author's article Smetana's 'Vyšehrad' and Mythologies of Czechness in Scholarship, 19th-Century Music, vol. 37 (2013), pp. 91-112.

14 WHITTALL, Arnold. Exploring Twentieth-Century Music: Tradition and Innovation, Cambridge, etc: Cambridge University Press, 2003, p. 34. Chapter 3 of this book, "Rites of Renewal and Remembrance", compares the music of Janáček with that of Bartók, and draws on a paper on Janáček originally given at the Janáček Conference in London in 1999. 
NEJEDLÝ, Zdeněk. Bedřich Smetana, 4 volumes, Praha: Hudební matice Umělecké besedy, 1924-33

STORCK, Christopher P. Kulturnation und Nationalkunst: Strategien und Mechanismen tschechischer Nationsbildung von 1860 bis 1914, Mittel- und Osteuropawissenschaften, Geschichte, Köln: Verlag Wissenschaft und Politik, 2001

ST PIERRE, Kelly. Smetana's 'Vyšehrad' and Mythologies of Czechness in Scholarship. 19th-Century Music, vol. 37 (2013), pp. 91-112

ST PIERRE, Kelly. Bedřich Smetana: Myth, Music, and Propaganda, Eastman Studies in Music, Rochester, NY: University of Rochester Press, 2017

SVAZ ČESKOSLOVENSKÝCH SKLADATELU゚, Brno branch, typescript minutes of meeting held on 16 June 1952 (manuscript without shelfmark, accessed in Institute of Musicology, Masaryk University, Brno)

SYCHRA, Antonín. Stránická hudebni kritika spolutvuirce nové hudby: Úvod do hudebni estetiky socialistického realismu, Za novou hudbu, vol. 3, Praha: Orbis, 1951

TYRRELL, John. Janáček and the Speech-Melody Myth. The Musical Times, vol. 111 (1970), pp. 793-796

WHITTALL, Arnold. Exploring Twentieth-Century Music: Tradition and Innovation, Cambridge, UK: Cambridge University Press, 2003 
